\title{
Illness Perception, Knowledge and Self-Care about Cervical Cancer
}

\author{
Percepção da Doença, Conhecimento e Autocuidado \\ sobre o Câncer do Colo do Útero
}

\author{
Elisa Kern de Castro ${ }^{*},{ }^{a}$, Ana Carolina Peuker ${ }^{a}$, Priscila Lawrenz $^{a} \&$ Maria João Figueiras $^{b, c}$ \\ ${ }^{a}$ Universidade do Vale do Rio dos Sinos, São Leopoldo, RS, Brazil, ${ }^{b}$ Instituto Piaget, Almada, Portugal \\ $\&{ }^{c}$ Instituto Superior de Psicologia Aplicada de Lisboa, Lisboa, Portugal
}

\begin{abstract}
Prevention plays a central role in early detection of cervical cancer. Common Sense Model proposes that the nature and organization of illness representations can guide actions related to health and how self-care is exercised. The aim of this study was to describe and compare illness perception, knowledge and self-care in women with and without cancer precursor lesions. Participants were 92 women (aged 18-59) from primary care unity divided into two groups: women with and without premalignant lesion. Measures for illness perception, knowledge and self-care were used. There was no statistically significant difference ( $t$ test e chi-square test) between groups in the variables analyzed. Despite the risk for cervical cancer, women with precursor lesions do not adjust their illness perceptions, knowledge and self-care to the situation. These data show the need to warn women against the cervical cancer risks, because their distorted perceptions and lack of knowledge about the disease may hamper the screening and control of cervical cancer.

Keywords: Common sense model, self-regulation, cervical cancer, human papillomavirus.
\end{abstract}

\begin{abstract}
Resumo
A prevenção tem papel central na detecção precoce do câncer do colo do útero. O Modelo do Senso Comum propõe que a natureza e a organização das representações da doença podem orientar ações relacionadas à saúde e ao modo como o autocuidado é exercido. Este estudo buscou caracterizar e comparar a percepção da doença, o conhecimento e o autocuidado em mulheres com e sem lesões precursoras de câncer do colo do útero. Participaram 92 usuárias de uma Unidade Básica de Saúde (18-59 anos), dividas em dois grupos pareados por idade e escolaridade: com e sem lesões precursoras do colo do útero. Foram utilizados instrumentos de avaliação da percepção da doença, conhecimento sobre o câncer do colo do útero e autocuidado. Não houve diferenças estatisticamente significativas (teste $t$ e qui-quadrado) entre os grupos quanto às variáveis investigadas. Apesar de estarem em risco para o câncer do colo do útero, as mulheres com lesões precursoras não ajustaram sua percepção da doença, conhecimento e autocuidado à situação. Esse dado alerta para a necessidade de sensibilizar as mulheres sobre o risco da doença, já que percepções errôneas e o desconhecimento sobre a doença podem dificultar o seu amplo rastreio e controle.

Palavras-chave: Modelo do senso comum, autorregulação, câncer cervical, papilomavírus humano.
\end{abstract}

Cervical cancer (UCC) is the second most common type of cancer in women worldwide. Almost $80 \%$ of cases occur in developing countries (World Health Organization [WHO], 2013). In Brazil, it is estimated that 15,590 new cases of the disease will be diagnosed in 2014. Infection by Human
Papilloma Virus (HPV) is one of the main risk factors for the development of UCC. This virus is present in $98 \%$ of cases of cervical cancer, although it is not the only variable associated with the emergence of the disease (Instituto Nacional do Câncer [INCA], 2014a).

\footnotetext{
* Mailing address: Universidade do Vale do Rio dos Sinos, Centro de Ciências da Saúde, Avenida Unisinos, 950, Sala 2B112, Cristo Rei, São Leopoldo, RS, Brazil 93022-000. E-mail: elisa.kerndecastro@gmail.com, acpeuker@hotmail.com, priscila.lawrenz@gmail.com and figueirasmar@gmail.com

Acknowledgments: The authors thank the nurse Maria Rejane Seibel and the whole team of gynecology at UBS (Unidade Básica de Saúde) IAPI for the interest and willingness to collaborate with the research.
}

Conflict of interest: This study received financial support from the Department of Science and Technology of the Secretary of Science, Technology and Strategic Inputs from the Ministry of Health (DECIT/SCTIE-MS), through the Conselho Nacional de Desenvolvimento Científico e Tecnológico (CNPq) and the Fundação de Amparo à Pesquisa do Rio Grande do Sul (FAPERGS). Published Pronem (Programa de Apoio a Núcleos Emergentes de Pesquisa): 03/2011; number: 11/2067-4. 
UCC is a common type of cancer, especially in women between 20 and 39 years of age. Changes in cells that may lead to the development of UCC can be previously identified through preventive examinations, such as Pap smears. In developed countries, its incidence and mortality rates have decreased, which is attributed largely to early detection (INCA, 2014a; WHO, 2013). With proper screening and early detection, the progression of precancerous cervical lesions can be completely avoided in most cases. In early stages, the UCC is highly treatable. However, the onset of the disease is associated with, among other factors, low socioeconomic status and difficulties of access to health services (Amaral et al., 2006; Parada et al., 2009; WHO, 2013). Despite the efforts in the implementation of prevention programs, mortality rates have not suffered significant changes over the last two decades in Brazil (Albuquerque et al., 2012; Parada et al., 2009).

In Brazil, many factors make the prevention and control of UCC a great challenge. The scarcity of financial resources, the limitations of the health care services and information system, hinder broad disease screening (Amaral et al., 2006). A retrospective study conducted in the Central-West region of Brazil investigated whether women with atypias of undetermined significance, precursor or invasive lesions had been forwarded to a Medium Complexity Unit, as per the Ministry of Health guidelines. From the analysis of 832 records, the results showed that $72.7 \%$ of referrals did not follow that recommendation (Albuquerque et al., 2012).

Early detection has a central role in combating UCC (Albuquerque et al., 2012; INCA, 2014a; WHO, 2013). Therefore, with regard to the control of the disease, vaccination, social mobilization actions and training of health care professionals are crucial to the improvement of the tracking programs (WHO, 2013). In addition, psychological issues and behavioral factors should be considered when delineating public health policies (Castro \& Bornholdt, 2004).

With regard to psychological issues, the representation built by the individual about the disease ("mental model") - which includes the beliefs and perception of risk and the illness-can have an impact on the way the person exercises self-care (Maes \& Karoly, 2005). Self-care refers to a set of actions performed by the individual in order to maintain her health, life and well-being. In the context of health, this concept differs from the traditional medical model of healing, since the individual retains an active role with responsibility for their own health (Castro \& Moro, 2012).

The Common Sense Model proposes that the nature and organization of representations about the disease can guide actions that are related to health, to the way in which the patient exercises self-care and how to face her problem (Leventhal, Nerenz, \& Steele, 1984). According to this theoretical model, the actions taken to reduce health risks are guided by the individual's subjectivity and by constructions based on common sense about the health threat. Thus, the disease is represented by its dimensions: identity (possible symptoms of the disease), causes (factors that give rise to the disease), timeline (course of the disease over time; e.g., acute or chronic, cyclic), consequences (severity of the disease and its impact on the physical, psychological and social functioning), personal control (perception of how the patient can control or cure the disease), the control of treatment (treatment effectiveness to control or cure the disease), consistency of the disease (perception of how an individual understands the disease) and emotional representation (emotions involving the experience of illness; Leventhal, Brissette, \& Leventhal, 2003).

The mental model about the disease is formed from the representations of the reality and health condition that the individual possesses, as well as observation of the experiences of people close. These representations do not always approach the reality of what it's like to have the disease, including its forms of prevention. In this sense, an important concept for preventive actions, health-wise, is the perception of being at risk (Bish, Ramirez, Burgess, \& Hunter, 2005; Shiloh, Drori, Orr-Urtreger, \& Friedman, 2009).

The perceived risk - consisting of the perception, identification and attribution of symptoms to the disease (cancer of the cervix, in this case) is the first step in the process of seeking help (Bish et al., 2005). The knowledge of the risk factors that lead to the development of UCC is associated with the pursuit of a Pap smear. It is possible that the perception of risk and cultural beliefs affect screening rates more than the lack of knowledge regarding the importance of the Pap smear. Beliefs about individual vulnerability and the knowledge about the severity of UCC are among the factors that have been linked to the fact that some women having never, or rarely, performed a triage. Few women relate the risk of cervical cancer with sexually transmitted HPV (Waller, McCaffery, \& Wardle, 2004).

Unfamiliar symptoms can generate erroneous beliefs, self-diagnosis and underestimating the need for aid. In these cases, one might delay seeking medical help and aggravate the health problem. For example, women without prior knowledge of UCC, associated risk factors, with erroneous beliefs about its causes, symptoms and consequences may neglect the need to perform the preventive exam. In a study developed in hospitals that compared women with UCC, women with precursor lesions of UCC and healthy women found the latter perceive the disease as more symptomatic (identity dimension) and cyclic (cyclic route dimension) than the other groups. The group of women with UCC attributed the origin of the disease to emotional aspects, differing from the other two groups. These findings may have repercussions in the early detection of the disease and in a woman's self-care (Castro, Aretz, Lawrenz, Romeiro, $\&$ Haas, 2013). Thus, it is important to deepen the awareness of the behavior necessary for prevention of UCC, as is also the case of self-care. This study had as its objectives: (a) describe the profile of the illness perception, level of knowledge and self-care actions with and without UCC precursor lesion and; (b) compare the illness perception, the level of knowledge about UCC and the self-care in 
Castro, E. K., Peuker, A. C., Lawrenz, P. \& Figueiras, M. J. (2015). Illness Perception, Knowledge and Self-Care about Cervical Cancer.

women with and without precursor lesions in the context of Basic Healthcare Units (BHU).

\section{Method}

\section{Participants}

Ninety-two women, users of a BHU located in Porto Alegre - RS, participated. The selection of the sample was non-probabilistic, for convenience, sampling method used in human behavioral science (Cozby, 2003). The sample was divided into two groups: a group of women who presented UCC precursors $(n=46 ; 36$ years on average; $S D=12$ ), called the Clinical Group (CG) and another of women without $\mathrm{UCC}$ precursor lesions $(n=46 ; 36$ years on average; $S D=11$ ), Non-Clinical Group (NCG). The NCG was paired by age and schooling with the CG from a larger sample $(N=135)$ of users of the same BHU who performed routine gynecological consultations in the period September 2012 to March 2013. Excluded from the sample were teenagers ( $<18$ years), Elderly ( $>60$ years), pregnant women who were performing gynecological prenatal follow-up consultation and women with previous history of UCC, as per medical records.

\section{Instruments}

Bio-Social-Demographics and Clinical Data Questionnaire. Instrument with questions relating to the characterization of the sample, such as: sex, age, marital status, education, profession and health history. Included two closed questions on Health Self-Assessment: "In General, how would you rate your health today?" and "How do you think your family would currently rate your state of health?", with answer options: excellent, good, moderate, bad and terrible.

Assessment Scale of Self-Care Capabilities (ASS-C). Evaluates the conduct of self-care from 24 items, with options of responses on a Likert scale of 1 to 5 . The items refer to availability, willingness and capacity to modify and improving their lives; care as to diet, hygiene, and weight. The items also assess whether individuals seek to carry out adaptations to improve their own health and seek support networks in case of difficulties with self-care procedures. Matters relating to risky sexual behavior were also included.

Revised Illness Perception Questionnaire for Healthy People (IPQ-RH; Figueiras \& Alves, 2007). Instrument adapted from IPQ-R (Moss-Morris et al., 2002) with the objective of evaluating the beliefs about the disease according to the Common Sense Model (Leventhal et al., 2003). Assesses what healthy people think about health and a specific disease, and how their ways of thinking are related to health-related behaviors. The instrument is divided into three dimensions. The first, called identity, 17 symptoms commonly known are presented (e.g. pain, dizziness, etc.) and the participants are invited to respond if they believe or not that these symptoms are related to the disease. The sum of the number of answers "Yes" determines the score of this dimension. The second dimension includes the sub-scales consequences, treatment control, coherence, emotional representation, chronic/acute timeline, cyclic timeline and personal control. The third dimension is related to the possible causes of the disease, divided into psychological and general attributes. Both come with a five-point Likert scale. As the IPQ-RH is an instrument that can be applied with healthy populations investigating the perception of different diseases, it can be adapted to the sample under analysis. However, it is recommended to review the psychometric properties of the instrument in each case. In this study were included in the analysis only the sub-scales with Cronbach's Alpha equal to or greater than .60 to ensure greater data reliability. The sub-scales used Alpha obtained ranged from .61 (control treatment) to .90 (emotional representation). Thus, the acute/chronic timeline sub-scales, cyclic timeline and personal control were excluded.

Questionnaire on Women's Knowledge about Cervical Cancer. Instrument adapted from Women's knowledge about breast cancer and cervical cancer (Silva, Franco, \& Marques, 2005). The original instrument consists of 22 questions that assess knowledge about symptoms, severity and treatment of breast cancer and UCC. The questionnaire was adapted to be used in this study. Only the questions pertaining to UCC were maintained - eight multiple-choice questions (five options and only one is correct). The total score was obtained from the score assignment to correct questions (one) and wrong (zero).

\section{Procedures}

The women were invited to participate in the study after performing a gynecologic consultation at the BHU. Prior to data collection, the participants were informed about the objectives, risks and benefits in participating, on the voluntary nature of participation and the guarantee of privacy regarding the identification data. Thus, all those who agreed to participate in the study signed a Informed Consent Form (ICF). After the signing of the ICF, the instruments of research were applied. The $\mathrm{CG}$ was established on the basis of referrals made by doctors, which previously triaged the cases with and without UCC precursor lesions selected from the analysis of tests, smears and those indicated for participation in the study. With regard to ethical aspects, the project was approved by the Research Ethics Committee (REC) of the Porto Alegre's Secretary of Health, docket number 001.008580.12.0, registration in the REC number 756, issued on 04/10/2012.

\section{Analysis of Data}

Data was analyzed through descriptive statistics of the variables studied in terms of frequency of distribution, scores, averages and standard deviation. The analyses were stratified considering the presence or not of UCC precursor lesions. Using inferential statistics-Chi-square test for the comparison of groups with regard to categorical variables and Student's $t$ test for comparison of intervallic variables. 
A significance level of 5\% was adopted. The analyses were performed using the SPSS (Statistical Package for the Social Sciences) version 20.0.

\section{Results}

\section{Characterization of the Sample}

Table 1 presents the socio-demographic characteristics of the sample, according to the group to which they belong. In relation to self-care, $91.3 \%$ of CG and $89.1 \%$ of the NCG replied using the health services regularly. Most of them, in both groups CG $(87 \%)$ and NCG $(84.8 \%)$ claimed to have the habit of going to the gynecologist and more than $80 \%$ of women claimed to have consulted within the last year. In relation to periodicity, $41.3 \%$ of CG and $56.5 \%$ of NCG reported annual visits to the gynecologist. The percentage of women who claimed to see two or more times a year was higher in the CG $(45.7 \%)$ than in the NCG (28.3 percent). In the CG, $13 \%$, and at NCG, $15.2 \%$ are not accustomed to going to the gynecologist. As for the preventive examination, more than $70 \%$ of the women in both groups had a Pap smear in the last year, rising to $89.1 \%(\mathrm{NCG})$ and $80.4 \%(\mathrm{CG})$ in the past three years.

Table 1

Distribution of Demographic Variables among the Participants, according to the Groups - CG (clinical group) and NCG (non-clinical group)

\begin{tabular}{lcccccc}
\hline & $\begin{array}{c}\text { CG } \\
(n=46)\end{array}$ & & \multicolumn{2}{c}{ NCG } & \\
$(n=46)$ & \\
\hline & $f$ & & $\%$ & $f$ & & $\%$
\end{tabular}

Has fixed companion?

Yes

34

01

11

Elementary school

High school

Higher education

26

08
Ethnicity

White

Black

Mixed

East Asian

Work?

Yes

Monthly income (family)

5 to 15 minimum wages

3 to 5 minimum wages

1 to 3 minimum wages

Up to 1 minimum wage

Have children?

Yes

33

36

06

02

02

04

17

19

06
73.9

37

80.4

2.2

23.9

01

56.5

17.4

26

17.4

08

78.3

40

87.0

13.0

03

6.5

4.3

03

6.5

4.3

52.1

31

67.4

8.7

07

15.2

37.0

18

39.1

41.3

19

41.3

13.0

02

4.3

Note. $N=92$. 
Castro, E. K., Peuker, A. C., Lawrenz, P. \& Figueiras, M. J. (2015). Illness Perception, Knowledge and Self-Care about Cervical Cancer.

Illness Perception, Knowledge and Self-Care

No differences were found in the dimensions NCG and CG sub-scales evaluated. The results of the comparison of averages ( $t$ Test) are shown in Table 3. In the identity dimension, the averages obtained by the two groups show that the participants attach few symptoms to UCC, in view of the variation from zero to seventeen. The other sub-scales were interpreted considering a variation range of zero to five, according to the Likert scale. With regard to the consequences, the averages of the groups were close to four, showing that the UCC is perceived as a disease with serious consequences. As for the control of the treatment, the participants in both groups considered that the treatment is effective, because its averages were greater than four. On the coherence sub-scale, averages of the groups suggest that patients believe that partially understand the disease, since these values are located just above the midpoint - three. Emotional representation results suggest that the participants consider the disease as moderately threatening. The data indicate that the groups assign few psychological causes to the emergence of UCC, however, attach to the disease more general causes.

The groups did not have significant differences regarding the knowledge of the disease by $t$ test total scores of correct responses on UCC. Participants in both groups showed around a $58 \%$ knowledge of UCC, since the CG obtained an average of $4.73(S D=1.03)$ and the NCG of $4.69(S D=1.68)$. However, the $\mathrm{x}^{2}$ test revealed that women of the CG had more knowledge than the NCG in question 01 , that listed items with virus types and possible tests to be carried out to detect the presence of UCC. CG women had more knowledge that the HPV virus is present in most cases of UCC and that the Pap smear is the most effective for lesions than women of the NCG. In quantitative terms, of the 46 women on the $\mathrm{CG}$ just three missed this question. In the NCG, of the 46 women, 12 marked the wrong alternative $(p<.05)$. Also no statistically significant difference was found between the groups $(p=.508)$ in relation to Self-care. The results are presented in Table 2.

Table 2

Comparison of Perception of Disease, Self-Care and Knowledge among Groups CG and NCG (Averages, Standard Deviation, $t$ Test)

\begin{tabular}{|c|c|c|c|c|}
\hline & $\mathrm{CG}(n=46)$ & $\operatorname{NCG}(n=46)$ & & \\
\hline Variable & Mean $(S D)$ & Mean $(S D)$ & $t$ & $p$ \\
\hline Identity & $5.02(3.28)$ & $5.02(3.12)$ & .00 & 1.00 \\
\hline Consequences & $3.70(.87)$ & $3.88(.66)$ & -1.11 & .27 \\
\hline Treatment control & $4.26(.49)$ & $4.19(.51)$ & .69 & .49 \\
\hline Coherence & $3.21(1.02)$ & $3.38(1.12)$ & -.75 & .45 \\
\hline Emotional representation & $3.35(1.24)$ & $3.23(1.13)$ & .45 & .64 \\
\hline Causes-psychological attributes & $2.12(.05)$ & $2.07(.64)$ & .42 & .67 \\
\hline Causes - general attributes & $3.63(.62)$ & $3.84(.65)$ & -1.58 & .11 \\
\hline Self-care (Total) & 91.94 (14.95) & $91.86(12.92)$ & .02 & .98 \\
\hline Knowledge (Total) & $4.73(1.03)$ & $4.69(1.38)$ & .17 & .86 \\
\hline
\end{tabular}

\section{Self-Evaluation of Health Condition}

When asked "How would you rate your health?" $69.5 \%$ of women of the CG and $67.4 \%$ of the NCG rated their health as "Excellent" or "Good". However, $30.2 \%$ of participants of the CG and $32.6 \%$ of the NCG classified as "Moderate" or "Bad". When challenged, "How would a family member rate your health status?" $63 \%$ of women of the CG and $69.6 \%$ of the NCG reported that her health would be classified by a family member as "Excellent" or "Good". While, $36.9 \%$ of CG and $30.4 \%$ of the NCG stated that the family would rate their health condition as "Moderate" or "Bad". The comparison analysis of the answers through the $\mathrm{X}^{2}$ showed no significant differences between the groups.

\section{Discussion}

This study investigated important aspects regarding the perception of UCC, the conduct of self-care and the level of knowledge about the disease in women with and without precursor lesions in the context of primary health care. The most noteworthy result refers to the fact that the two groups of women assessed, CG and NCG, had not presented differences regarding the illness perception, knowledge and self-care.

The absence of symptoms (Identity dimension) of UCC is an aspect that may have reflected the perception about the disease in women with lesions, since this data resembles women without precursor lesions. The lesion, most often 
is asymptomatic, and for many women the risk of UCC development may not be properly represented, since most describe her state of health as good and excellent, and assign few symptoms. According to the Common-Sense Model, representations of the disease are dynamic and auto-regulated after the assessment of the significance of somatic stimuli, location, timeline and sensory pattern, affecting her emotional state and the mechanisms of action in response to these symptoms (McAndrew et al., 2008). This means that there is an active process in assigning meaning and emotional reactions to the somatic stimuli, affecting selection of coping mechanisms and the creation of specific action plans. It would be logical that women with precursor lesions had a more adjusted perception (close to reality) than the other group, especially as regards the possible absence of symptoms such as UCC lesions. However, the similarity in the outcomes of the two groups can give indications that women with no lesions didn't acquire more knowledge with the experience of her health problem. It is possible that this assessment of significance of the lesions on the part of the affected woman is faulty, since the threat may not be interpreted properly since it is an internal lesion, "not visible" and not palpable by the woman. This fact may be related to a difficulty of communication and understanding between the health professional and the patient at the moment of diagnosis, who should emphasize the risk of lesions to the emergence of UCC.

The result altered by tracing is not always coupled to a good understanding by the woman of what cervical cell changes mean (Hounsgaard, Augustussen, Moller, Bradley, \& Moller, 2013). In this study, although the participants perceive the UCC as a disease with serious consequences, their individual risk perception was not compatible with these data. Health professionals need to develop effective skills of communication to inform about the relationship between the precancerous lesions and UCC. However, such communication must involve caution and to avoid being alarmist. The exacerbation of anxiety may impair the proper representation of the disease, making it very threatening, enough to generate feelings of powerlessness and prevent self-care. On the other hand, the communicational aspect has not been evaluated in this study and can be the subject of future studies.

Exposure to care environments can assist women to associate the precursor lesion to the need for care and the risk of the UCC and thus adjust their perception of illness, approaching her to reality. According to this hypothesis, a study that strengthens this assumption (Castro et al., 2013) revealed that healthy women represented the UCC as a more symptomatic disease than women with UCC precursor lesion and with UCC in the hospital environment. Exposure to hospital environment can activate an adjustment of the perception in a woman, approaching her to reality, especially in relation to the dimension Consequence of the disease. In this context, the woman with a lesion may, by vicarious experience, amplify or even acquire a clearer understanding of the serious consequences of UCC, which starts with an asymptomatic lesion.
In relation to the knowledge of women about UCC, the absence of differences between the groups (except in the first question) may be demonstrating that, after initial period of anxiety resulting from the altered examination, women can be afflicted by a necessity in obtaining (further) information (Bertram \& Magnussen, 2008). Many women, before they have had an altered Pap smear didn't know the relationship between HPV and UCC. However, after the result, tend to look for knowledge through various sources.

On the other hand, the information obtained by women with lesions may not be enough to clarify all her doubts. Not always is the professional-patient communication established in an appropriate manner, in the light of limited time for consultation, the use of jargon, communication style, among other aspects. The internet, despite offering abundant information, can also contribute to increasing doubt. Similarly, family and friends, although they offer emotional support, may not precisely inform about the disease (Bertram \& Magnussen, 2008).

Before the advertising of the HPV vaccine, public awareness about this sexually transmitted virus was small and its dissemination in the media favored increased awareness on the subject. However, the information disseminated does not cover the meaning of precursor lesions and risk factors of development of UCC in depth, nor regarding the limitations of vaccine coverage. In relation to this last point, the HPV vaccine, which was included in the Brazil's Ministry of Health 2014 calendar, protects against the most harmful types of viruses. However, the long-term effects of the vaccine are not yet known. The false sense that women are completely immunized against HPV and, consequently, UCC, could contribute to overlook self-care, including failing to have a Pap smear regularly, and expose herself to risky sexual behaviors (INCA, 2014b).

In short, a comprehensive approach directed to prevention of UCC and the benefits of its control may involve actions ranging from the environmental level to the individual. At the environmental level, is part of the social mobilization, vaccination campaigns, systematic tracing programs and the training of health professionals (WHO, 2013). At the individual level, the focus of interventions can be directed to psychological aspects, such as the modification of distorted beliefs about the disease and to the increase in knowledge of UCC, since the perceptions about the disease and ignorance may reflect negatively on how self-care is exercised (Castro et al., 2013; Kim et al., 2008). It would be ideal if self-care was exercised with autonomy, appropriate knowledge about what is being prevented and criticism about the factors that interfere in the disease-health process. In general, women can perform tests automatically by medical indication, without necessarily understanding what this stands for and the impact of its result on her health.

The results of this investigation should be interpreted with caution due to the absence of data on severity of precursor lesions that women presented (degree of cervical intraepithelial neoplasia [CIN]), because this can be a moderating variable of perception of risk, since in the case 
of CIN I spontaneous regression rate is around $60 \%$ while only $1 \%$ of cases evolves into cancer (Rosa et al., 2009).

The non-randomness of the sample, selected in the context of public primary health care, and the fact that the sample be comprised of predominantly white women, with fixed companions, children, average schooling level and participating in the labor market must also be observed. Given this, the results obtained should be analyzed considering such characteristics, and cannot be extrapolated to populations with distinctly (different) socio-demographic conditions. Despite the fact that these findings cannot be generalized, they assist in better understanding the way women perceive UCC, their level of knowledge and their preventive actions, may support efforts in public health, preventive actions and intervention studies.

\section{References}

Albuquerque, Z. B. P., Manrique, E. J. C., Tavares, S. B. do N., Souza, A. C. S., Guimarães, J. V., \& Amaral, R. G. (2012). Mulheres com atipias, lesões precursoras e invasivas do colo do útero: Condutas segundo as recomendações do Ministério da Saúde. Revista Brasileira de Ginecologia e Obstetrícia, 34(6), 248-253. doi:10.1590/S0100-72032012000600002

Amaral, R. G., Ribeiro, A. A., Miranda, F. A., Tavares, S. B. do N., Souza, N. L. A., Manrique, E. J. C., ...Fonsechi-Carvasan, G. A. (2006). Fatores que podem comprometer a qualidade dos exames citopatológicos no rastreamento do câncer do colo do útero. Revista Brasileira de Análises Clínicas, 38(1), 3-6. doi:10.1590/S0100-72032008001100005

Bertram, C. C., \& Magnussen, L. (2008). Informational needs and the experiences of women with abnormal papanicolaou smears. Journal of the American Association of Nurse Practitioners, 20(9), 455-462. doi:10.1111/j.17457599.2008.00341.x

Bish, A., Ramirez, A., Burgess, C., \& Hunter, M. (2005). Understanding why women delay in seeking help for breast cancer symptoms. Journal of Psychosomatic Research, 58, 321-326. doi:10.1016/j.jpsychores.2004.10.007

Castro, E. K. de, Aretz, M., Lawrenz, P., Romeiro, F. B., \& Haas, S. A. (2013). Illness perceptions in Brazilian women with cervical cancer, women with precursory lesions and healthy women. Psicooncologia, 10(2), 417-423. doi:10.5209/ rev_PSIC.2013.v10.n2-3.43459

Castro, E. K. de, \& Bornholdt, E. (2004) Psicologia da saúde x psicologia hospitalar: Definições e possibilidades de inserção profissional. Psicologia: Ciência e Profissão, 24(3), 48-57. doi:10.1590/S1414-98932004000300007

Castro, E. K. de, \& Moro, L. (2012). Factores psicosociales relacionados con el autocuidado en la prevención, tratamiento y postratamiento del câncer de mama. Psicooncologia, 9(3), 453-465. doi:10.5209/rev_PSIC.2013.v9.n2-3.40916

Cozby, P. C. (2003). Métodos de pesquisa em ciências do comportamento. São Paulo, SP: Atlas.

Figueiras, M. J., \& Alves, N. C. (2007). Lay perceptions of serious illnesses: An adapted version of the Revised Illness Perception Questionnaire (IPQ-R) for healthy people. Psychology \& Health, 22(2), 143-158. doi:10.1080/14768320600774462

Hounsgaard, L., Augustussen, M., Moller, H., Bradley, S. K., \& Moller, S. (2013). Women's perspectives on illness when being screened for cervical cancer. International Journal of Circumpolar Health, 72, 1-7.
Instituto Nacional do Câncer. (2014a). Estimativas 2014 - Incidencia de câncer no Brasil. Retrieved from http://www.inca. gov.br/estimativa/2014/.

Instituto Nacional do Câncer. (2014b). Vacinas contra infecção pelo HPV: Ainda existem várias dúvidas. Retrieved from http://www.inca.gov.br/impressao.asp? op=pr\&id=1933

Kim, S. E., Pérez-Stable, E. J., Wong, S., Gregorich, S., Sawaya, G. F., Walsh, J. M. E., \& Kaplan, C. P. (2008). Association between cancer risk perception and screening behavior among diverse women. Archives of Internal Medicine, 168(7), 728-734. Retrieved from http://www.readcube.com/articles/10.1001/archinte.168.7.728

Leventhal, H., Brissette, I., \& Leventhal, E. A. (2003). The common-sense model of self-regulation of health and illness. In L. D. Cameron \& H. Leventhal (Eds.), The self-regulation of health and illness behavior (pp. 42-65). London: Routledge.

Leventhal, H., Nerenz, D. L., \& Steele, D. J. (1984). Illness representation and coping with health threats. In A. Baum, S. E. Taylor, \& J. E. Singer (Eds.), Handbook of psychology and health (pp. 219-252). Hillsdale, NJ: Lawrence Erlbaum.

Maes, S., \& Karoly, P. (2005). Self-regulation assessment and intervention in physical health and illness: A review. $A p$ plied Psychology: An International Review, 54, 267-299. doi:10.1111/j.1464-0597.2005.00210.x

McAndrew, L. M., Musumeci-Szabo, T. J., Mora, P. A., Vileikyte, L., Burns, E., Halm, E. A., ...Leventhal, H. (2008). Using the common sense model to design interventions for the prevention and management of chronic illness threats: From description to process. British Journal of Health Psychology, 13, 195-204. doi:10.1348/135910708X295604

Moss-Morris, R., Weinman, J., Petrie, K. J., Horne, R., Cameron, L. D., \& Buick, D. (2002). The revised Illness Perception Questionnaire (IPQ-R). Psychology \& Health, 17, 1-16. doi:10.1080/08870440290001494

Parada, R., Assis, M., Silva, R. C., Abreu, M. F., Silva, M. A., Dias, M. B. K., \& Tomazelli, J. G. (2009). A política nacional de atenção oncológica e o papel da atenção básica na prevenção e controle do câncer. Revista de APS: Atenção Primária à Saúde, 11, 199-206.

Rosa, M. I., Medeiros, L. R., Rosa, D. D., Bozetti, M. C., Silva, F. R., \& Silva, B. R. (2009). Papilomavírus humano e neoplasia cervical. Cadernos de Saúde Pública, 25(5), 953-964. doi:10.1590/S0102-311X2009000500002

Shiloh, S., Drori, E., Orr-Urtreger, A. O., \& Friedman, E. (2009). Being 'at risk' for developing cancer: Cognitive representations and psychological outcomes. Journal of Behavioral Medicine, 32, 197-208. doi:10.1007/s10865-008-9178-Z

Silva, N. C. B., Franco, M. A. P., \& Marques, S. L. (2005). Conhecimento de mulheres sobre câncer de mama e de colo do útero. Paidéia (Ribeirão Preto), 15(32), 409-416. doi:10.1590/ S0103-863X2005000300010

Waller, J., McCaffery, K., \& Wardle, J. (2004). Beliefs about risk factors for cervical cancer in a British population sample. Preventive Medicine, 38, 745-753. doi:10.1016/j. ypmed.2004.01.003

World Health Organization. (2013). Comprehensive cervical cancer prevention and control: A healthier future for girls and women. Retrieved from http://www.who.int/reproductivehealth/publications/cancers/9789241505147/en/ 